\title{
Physical Disability and Masculinity: Hegemony and Exclusion
}

\author{
Leslie Swartz, Bongani Mapumulo, and Poul Robleder
}

This book is part of a groundswell of research and activism around disability and sexuality. If you Google "disability and sexuality" you get almost 400,000 hits, and over 3000 on Google Scholar. There are disability and sexuality books, manuals, websites, and podcasts. Many, if not most, of these writings and productions have a similar aim to our own-to dispel myths about disability and sexuality and to assert the right of people with disabilities to sexual pleasure and expression, in whatever form they may wish to participate in sex, or define for themselves what participation in sex may mean.

In relation to disability and gender, it is often said that disability makes women seem less feminine and men less masculine. In other chapters in

\footnotetext{
L. Swartz $(\bowtie)$. B. Mapumulo

Department of Psychology, Faculty of Arts and Social Sciences, Stellenbosch University, Stellenbosch, South Africa

e-mail: lswartz@sun.ac.za

P. Rohleder

Department of Psychosocial and Psychoanalytic Studies, University of Essex, Colchester, UK

e-mail: p.rohleder@essex.ac.uk

(C) The Author(s) 2021

X. Hunt et al. (eds.), Physical Disability and Sexuality, https://doi.org/10.1007/978-3-030-55567-2_6
} 
this book, we discuss issues around women, disability and sexuality, but what does the idea that disability makes men seem less masculine mean, and does it apply, to how men who participated in this project and to how other men with physical disabilities see themselves? In this chapter, we will take a look at what the participants in our study said about this. In Chapter 7, Bongani Mapumulo describes some key issues that need to be taken into account when we think about physical disability and masculinity. He notes that all of us learn through processes of socialisation what it means to be a man or a woman, what the social roles are. These roles may change over time, but what is important for this chapter is the concept of hegemonic masculinity, which has a long history (Anderson \& McCormack, 2018; Connell \& Messerschmidt, 2005; Cornwall \& Lindisfarne, 2016; Messerschmidt, 2019).

Though there are many debates about the idea of power, the key concepts for purposes of this chapter include the principle that in most contexts worldwide, there is a difference in power between men and women (for reasons of historical and ongoing, ingrained social, political, and economic inequalities), and that men are expected to be strong, unemotional, and powerful leaders. As Messerschmidt (2019) notes in a very recent article, it is also accepted today that hegemonic masculinity is not fixed but changes with contexts and across time. It is also true, though, that in many discussions of what masculinity is and does, disability is hardly mentioned. For example, in the recent book edited by Cornwall and Lindisfarne (2016), disability is mentioned few times but there is no full discussion of disability. Similarly, introducing a recent book on masculinities, Gough (2018) notes that masculinity studies need to know more and engage more with the lives of men with physical disabilities, but there is no focus on disability.

A relatively new concept in masculinity studies is what is termed "inclusive masculinity theory" (Anderson, 2010a, 2010b; Anderson \& McGuire, 2010). The most recent article we could find stating the key outlines of the theory does not mention disability at all (Anderson \& McCormack, 2018), nor does disability tend to be mentioned in debates on this supposedly "inclusive" theory (see, for example, De Boise, 2015; Magrath \& Scoats, 2019; O’Neill, 2015; Scoats, 2017). For people who work in the field of disability studies, the word "inclusive" almost always implies including everybody, with people with disabilities being a key part of that inclusion (as in the term "inclusive education"). 
Inclusive masculinity theory, by contrast, distinguishes between what is termed "orthodox masculinity" which includes homophobic and misogynistic elements (in other words, elements of prejudice against gay people and against women), and "inclusive masculinity", which does not (Anderson, 2005; Anderson \& McGuire, 2010). Inclusive masculinity theory has usefully opened up space for debate, particularly on cultural changes around how gay men are seen, and on breaking the old stereotype that gay men are not really men.

It may be unfair to be pointing out how inclusive masculinity theory largely overlooks questions of disability ${ }^{1}$ as this is not really the focus of the theory. It is, furthermore, certainly the case that there are texts dealing with discrimination in a range of areas which do consider both homophobia and disablism (Kilvington \& Price, 2017). The key point we want to make here, however, is that even where the concept of "inclusion" is being thought about, many theorists are not thinking about disability as an inclusion issue. The feminist disability studies scholar Rosemarie Garland-Thomson $(1996,2009)$ often comments on how hidden disability is-that it is seen to be "nowhere", or that when it is revealed, it is often as a form of freak show. Garland-Thomson and others are working hard to change how disability can and should be made more visible (Sandell, Dodd, \& Garland-Thomson, 2013), but the general point remains: disability is often hidden and overlooked. This may be even more true in African, and especially rural, African contexts (Mji, Schneider, Vergunst, \& Swartz, 2014), and Swartz et al. (2018) have gone so far as to argue that the act of making disability invisible may be seen as a form of violence against people with disabilities.

Regardless of whether Swartz et al. (2018) are correct in seeing the invisibility of disability as a form of violence, the question remains how men with physical disabilities engage with their own sexuality and their sense of themselves as men. Hegemonic masculinity emphasises conventions like physical strength, dominance, and power over others (especially women), and these attributes may not be available to men with physical disabilities, or-at least-not in the way in which traditional conceptions of masculinity demand them.

${ }^{1}$ Anderson (2005) does briefly mention disability but only in the context of able-bodied athletes acquiring disabilities, permanently or temporarily, through sporting injuries. 
Alternative and shifting views of masculinity, with the recognition that just as there may be "orthodox masculinity" there may also be "inclusive masculinity" (Anderson \& McGuire, 2010), though critical of ideas about hegemonic masculinity, also tend to gloss over or ignore questions of disability and sexuality. Where, then, does this leave men with physical disabilities like the participants in the Disability o sexuality project? We would suggest that these are people who live with what we will term a double erasure - first, they tend to be excluded or side-lined from hegemonic masculinity, and even when theorists try to reformulate ideas about masculinity in more inclusive ways, they are again excluded. They are excluded from the work of societal repair that the idea of "inclusive masculinity" tries to undertake. ${ }^{2}$ This not only further excludes them, but also, paradoxically, makes their exclusion more complete-if as we move to make ideas about manhood and masculinity more complete, we keep excluding some men, we may seem more inclusive and hence we will not look for the continuing exclusions.

With these issues in the background, let's look at what our male participants said about themselves and about being a man.

\section{Being a Man: What Our Participants Said}

\section{Hegemonic masculinity}

It is clear from what our participants told us that they acutely feel the pressures consistent with the demands of hegemonic masculinity-men should be strong, powerful, and unemotional. Bongani, for example, speaks of the "alpha male" and of being "dominant", and Simon talks about the pressure to perform:

2 There are of course many men with disabilities who identify as gay, or who situate themselves across the LGBTIQA+ spectrum-so aspects of their masculinity and embodiment may well be covered to a degree by inclusive masculinity theory. As it happens, none of the participants in our study identified as LGBTIQA+, though we did try to include such participants in our study. For more discussion of the interface between disability and queer theory, please see McRuer $(2006,2018)$. Kunzel (2018) further notes that in the struggle to depathologise homosexuality, in the USA in particular, potential alignments between gay and disability politics may have been lost, as it was important for people who identify as LGBTIQA+, to declare themselves healthy and not deviant-and hence without disability. 
...whether I like it or not, there's almost a mainstream perception of what I mentioned: the alpha male, a breadwinner, a strong and unemotional person who is always rational, who is always one step ahead of everybody else and who is dominant within relationships within their immediate circle of friends. (Bongani)

...because you are the guy who is going to be the one that needs to perform the whole time. (Simon)

None of the people we spoke to suggested that this pressure was unique to men with physical disabilities, but all in various ways indicated that their lives were deeply affected by their not easily and obviously matching up to the hegemonic masculine norms. The most obvious deviation our participants had from these norms was in terms of their physical impairments, but many of them, as Bongani mentioned above, quickly linked ideas of masculinity to questions of economic power, such as being "the breadwinner". This emphasis on financial strength as part of masculinity was echoed by other participants:

...people would say that I can't contribute to society when it comes to employment. They would make statements like, You can't work. How can you work? (Tas)

You know, if you're not financially strong to support your partner and yourself, then the challenges are big. And the first thing women look for is stability - most of them - and I found that a lot. I mean, it's like, are you able to support me or not? I don't support you. (Simon)

In South Africa, the pressure for men to perform the role of primary breadwinner may be greater than in higher-income countries; according to national reports, a smaller proportion of women than men are employed, and, a larger proportion of women than men are not economically active (StatsSA, 2011). This could be due to a host of reasons, but one of these may be culturally, socially, and pragmatically determined role expectations for women (to raise children, and bear the burden of domestic and care work), and for men (to earn in the formal and informal economies).

In his discussion with us, Simon has taken the issue further-voicing what he imagines women say, or what he has heard, he makes the flat statement, as if from a woman to a man, "I don't support you”. What is 
interesting about this quote is that Simon is telling us here that he believes that women see certain roles as normal and natural-the statement "I don't support you" is absolutely emphatic, and Simon is not saying that women would prefer not to support men, but that women view it as a rule that women do not support men financially. Part of the talk around financial power as a feature of masculinity is the issue of perceptions of what men with physical disabilities can and cannot do. Tas articulates this very well here when he speaks in the voice of people in society, saying, "You can't work. How can you work?" These men have to live their lives operating against these incorrect perceptions of what men with physical disabilities can and cannot do.

When we look at how Simon and Tas discussed these issues with us, it's interesting to note that both of them did not just discuss how they are positioned as men, but they actually took on the voice of those they experience as positioning them in problematic ways. So we have:

Simon (voicing what a woman would say): I don't support you.

Tas (voicing what people without disability would say): You can't work. How can you work?

These injunctions about what gender roles are and should be, from the perspective of people Simon and Tas are talking about, are clear, straightforward and to the point. There is no ambiguity or shade of grey-the story is one of how men should be, how the world is, and how men with physical disabilities do not fit in. This is a form of what the disability studies scholar, Tom Shakespeare (2013), who has himself researched issues of disability and sexuality (Shakespeare, 1999, 2000; Shakespeare \& Richardson, 2018), would call "disavowal"-and the disavowal is powerful as it is voiced by our participants as a law, not a social choice or preference. This is how things are, and men with physical disabilities do not measure up. In this regard, another comment by Shakespeare (1999) is also relevant here. He suggests that for a range of reasons people with disabilities may be seen not just as not measuring up to ideals of masculinity in the case of men, or femininity in the case of women, but actually as constituting a kind of "third gender" (Shakespeare, 1999, p. 55)-neither male, nor female, but "disabled". For Shakespeare, writing at the turn of the twentieth century, part of this perception was instantiated by there being three kinds of toilets in 
public buildings_-"male", "female", and "disabled". This may seem a bit far-fetched, but let's think a bit about this. Twenty years ago, there was a strict division between sexes in terms of which public toilets they could use-men did not use women's toilets and vice versa. But men and women with physical disabilities used the same spaces. There are obvious practical reasons for this, but the physical ordering of space tells a story about the world, about who qualifies fully as a man or a woman. It is certainly true that the social ordering of public toilet spaces has changed over the past few years, with many more gender-inclusive toilets than before, partly because of issues related to recognition of transgender rights. It is also true that the issue of toilets and access to them remains a core issue for disability activism (Liddiard, 2017; Liddiard \& Slater, 2018). But for our thinking about what our participants said, the key issue here is the power of the social order which forces them to ask whether they qualify to be men at all.

An interesting feature of the talk of our participants, as we have quoted them above, is that some of the talk is about the body and the impairments themselves, but some is about a more symbolic form of power-the power of money. The men we spoke to all in various ways suggested that one way to qualify to enter the realm of being a man was through being financially strong, a provider, or, as Bongani put it, a "breadwinner". In a world in which financial strength is greatly valued, this is not surprising, and it is not uncommon for conventionally unattractive (and often older) men in our society to be able to attract sexual partners who are very attractive, young, and desirable. But in terms of disability and being a man, there is something more going on here. The word "breadwinner" speaks not only to financial independence, but also to the ability of someone to take care of dependants—as Simon voices what women may say: "I don't support you". An aspect of what our participants and other men with physical disabilities have to deal with in their lives is the perception that they will be dependant - financially or otherwise - in a world in which independence is valued, and is seen as a key feature of what it means to be a real man. The fact is that all human beings are dependent on others in some way-we are interdependent as a species (Kittay, 2013; Tronto, 1993), but the social tolerance of expectations around dependence are highly gendered-socially we are more likely to think of women as dependent, but of successful men as being independent (Held, 2018). This, as we shall see in the next section, has implications for how our participants experience themselves as men in sexual relationships with women. 
A further issue about how hegemonic masculinity may work is that of how men think about the status of women who become sexually involved with men with physical disabilities. Bongani puts it this way:

Is she going to be able to perceive this person as a complete male? Or, is it like a...I don't know... a diluted or minimised version of a man? Is she going to be settling for something less than what she can achieve? (Bongani)

Here, Bongani speaks not only of men with physical disabilities as not fully being men ("diluted or minimised") but also of how the woman may be perceived. She could be seen to be "settling for less", whereas she might have been able to achieve better or more. The idea of a sexual partner as a prize or an achievement is of course not anything new or unusual, but it does link to ideas about what has been termed commodification. A lot has been written about the commodification of women's bodies, whereby a male sexual partner is seen to "own" a woman's body as he would own an item of monetary value (McCloskey, Boonzaier, Steinbrenner, \& Hunter, 2016; Okeke-Ihejirika, Salami, \& Amodu, in press). The issue of commodification of women is also discussed in research which explores, amongst other things, how men with physical disabilities feel about paying sex workers to have sex with them (Abbott et al., in press) and in relation to the commercialisation of unusual women's bodies for purposes of (often titillating) entertainment (Williams, 2017). But in what Bongani says here, it is also the man's body which can be commodified and a source of capital for the woman. In the case of disability, he says, the (disabled) goods may be less valuable than what the woman might be able to "achieve". The issue of commodification of men's bodies is a relatively new topic in how we understand gender. A Google Scholar search on the exact terms "commodification of men's bodies" yielded only two hitsone an unpublished thesis from 2006, and the other a very recent article (Shahvaroughi Farahani, Sohrabi, Mazaherinejadfard, \& Hasan Larijani, 2018). A similar search on "commodification of women's bodies" yielded over 400 results. We believe that Bongani is on to something important here about ideas of masculinity in general, and this is an issue we return to in the section on recovering masculinity. 
2. Men with disabilities doing sex

Not surprisingly, a lot of what our participants spoke about was the pressure to perform sexually. They discussed the need to satisfy their partners sexually. As Simon put it:

What I have found, there's this thing of trying to prove yourself in trying to satisfy your partner. (Simon)

This emphasis on the need to satisfy women sexually is certainly not unique to men with physical disabilities (see, for example, Chadwick \& van Anders, 2017; Porter, Douglas, \& Collumbien, 2017), and some studies have even suggested that women's orgasms and pleasure in sexual experiences may be used by men as a way of measuring their own level of masculinity (Chadwick \& van Anders, 2017; Porter et al., 2017). This is in contrast to many views of hegemonic masculinity as embodying an emphasis on men taking pleasure in sexual conquests, with relatively little concern with the women's experience (Alldred \& Fox, 2015; Swartz, Colvin, \& Harrison, 2018). The transition to disablement, for men who acquire a disability, may go along with an increased emphasis on pleasuring a partner rather than taking one's own pleasure. As Sifiso puts it:

And now life is changing to be about someone else, but not yourself, but your partner. (Sifiso)

Here, Sifiso is talking about changes in sexuality after disablement, but as he goes on, he is talking about other issues which are not just about pleasing a female partner:

Ja, and you know males, they have this problem of will I be able to satisfy Joy? That is the male mind in our society. They're thinking oh, that guy is satisfying his girlfriend because he is coming circumcised from the bushes. Now will I also satisfy Joy? So those were the things that I was thinking. (Sifiso)

In discussing what he calls "the male mind in our society", Sifiso is taking as given that there is a "male mind"-a way that men think of themselves and other men. But he is saying something more-he speaks here of 
competition amongst men ("that guy is satisfying his girlfriend"). Importantly, the issue of satisfying a sexual partner is for Sifiso linked to how he may or may not measure up, not just in terms of pleasuring a woman, but in terms of how he compares to other men. So for Sifiso, within the intimacy of the sexual encounter with a female partner, there is also the presence of his feeling of how he is watched and judged, not by this woman, or by women in general, but by other men.

It is interesting that Sifiso here refers to "coming circumcised from the bushes" as a path to providing sexual pleasure for women. Within Xhosa, and some other, traditions in southern Africa, young men undergo a coming of age process known in isiXhosa as ulwaluko, part of which involves circumcision (Magodyo, Andipatin, \& Jackson, 2017; Mfecane, 2016). Colloquially, this secret process, to which women are not allowed access (Kiguwa \& Siswana, 2018), is known as "going to the bush", as the process is generally undertaken in the forests away from where people live. Men "coming...from the bushes", as Sifiso puts it, are men returning from their rituals (including circumcision) to society-and to women. Traditionally, as men are ritually circumcised without anaesthetic, at the moment of the pain of the cutting of the foreskin, they cry out, "Ndiyindoda" (Mfecane, 2016). This literally means, "I am a man". In society, Xhosa men who have not been ritually circumcised, regardless of their age, are known as "boys". The social significance of the ulwaluko process is profound, as Nelson Mandela (1995) discusses in his autobiography, and it has been suggested that failure to perform the ritual may lead to considerable emotional distress, and possibly even psychosis, let alone the stressful consequences of the process itself for those who undergo it (Le Roux et al., 2007; Swartz, 1986, 1987; Yen \& Wilbraham, 2003). Given the physical location of where the ceremonies are undertaken, and the physical privations for the process, not all men with physical disabilities can take part in the process. But as can be seen with the shout of "Ndiyindoda", this process is what turns a boy into a man-it is an absolute and clear marker of adult masculinity. The actual process by which urban South Africans find ways to declare themselves as socially fulfilling adult roles is more complicated than this and may relate centrally to issues of fertility and producing heirs (Swartz et al., 2018), which links to issues of reproductive rights discussed elsewhere in this book. Nevertheless, ulwaluko remains important, and the fact of the ritual process leads Sifiso to compare himself with men who have had the opportunity to shout out "Ndiyindoda" ("I am a man"). It is clear that this aspect 
of social comparison is very important, and penetrates into personal relationship spaces. Sifiso takes this issue of surveillance of sexual behaviour even further:

Satisfying my partner is very important. But for her it's not an important thing. She keeps on telling me that I must not worry about that. But for me, it is important. Because I know for a fact that if it was me, I'd also love to be satisfied. It is a part of life that must be completely done. But for her, she doesn't mind about being satisfied, but I prefer to everything to see her satisfied. (Sifiso)

In this account, Sifiso presents the issue of satisfying a partner as a selfevident prescription - the way things should be ("Satisfying my partner is very important"). He experiences this as important even if the partner herself says she is not concerned with this issue, and it may be helpful for us to think about three ways in which Sifiso may be thinking about his partner repeatedly "telling me that I must not worry about that". Three possibilities are:

1. The woman may kindly be wishing to protect Sifiso from her need for sexual pleasure-in order to protect him she may be lying.

2. It is not possible for the woman not to be concerned about sexual pleasure, as if Sifiso were in her position he would "also love to be satisfied".

3. Sexually satisfying a woman is a requirement of being a man-"It is a part of lie that must be completely done".

One of the challenges faced by anyone who does not, or cannot, fulfil dominant social roles is that others may patronise them-they may make allowances for them out of pity and condescension. Much has been written about this in the disability literature, with activists wanting equality and rejecting pity or charity (Longmore, 2015; Swartz, 2018)

\section{Recovering masculinity and sexuality}

Given the difficulties our participants have discussed above, how do they renegotiate their own masculinity and sexuality? Some of this, according to them, is a question of what men with physical disabilities do as part of sexual intimacy. As Nico puts it: 
Positions, yes, I'm sorry, and much more flexibility. Why I'm saying flexi, you're flexible in doing things. (Nico)

Linked to this are broader ways of signalling to women that the men themselves are sexual beings and value their own bodies. Tas says:

I still dress up. I still dress up to impress females. When a female sees me I believe that she needs to admire me when she looks at me, not just for being dressed up nicely, but also for my attitude as well. (Tas)

It is important here that the issue is not just about how men look, but how they communicate through their dress their own attitudes towards themselves. The question of who may be considered an appropriate sexual partner links to broader questions about how society is organised, as Tas notes:

One of the big things is, when I first became like an extra citizen in the community, after the whole reintegration process in society and become active again, and for me it was the first time I was part of something and I would get up in the morning and go to work. It was something very nice for me. It made me feel good. It made me feel like a man again. (Tas)

Here, Tas clearly articulates how in the process of disablement he moved from being a citizen in the community without having to claim his place, to being, as he puts it, an "extra", rather than a part of things. Tas's way out of this is through employment, an issue we have discussed above.

Regarding how to change things, it was Bongani, who, as we saw earlier, understood the male body with a physical disability possibly less of a prize or a commodity than is the normative male body without disability. For things to change, Bongani argues, it is not just men with physical disabilities who must change and adapt, but also their sexual partners:

No, he is a man in this relationship just like any other man would have been, which means embracing me in my entirety as opposed to taking those bits that make sense for her. (Bongani)

Here, in his expressing his wish to be embraced "in his entirety", Bongani is making a complex argument. First, he wants to be seen not just as a body but as a full human being. He wants the woman to be curious enough to get to know him as a whole "as opposed to taking those bits 
that make sense for her", as he puts it. Finally, this is a story of men with physical disabilities resisting being placed in a hierarchy of commodification, with their bodies being seen as less than the ideal. It is for the women to learn and accept that there is more to Bongani (and to any man with a disability) than the failure to live up to the stereotype of how men and men's bodies should be.

What is fascinating here is that in enjoining women to be partners in the project of reclaiming and reinvigorating men with physical disabilities' masculinity, Bongani is echoing much of the feminist literature on how women's bodies are seen and commodified-that literature calls on men to see women (and here we deliberately paraphrase Bongani's words)—in their entirety as opposed to taking those bits that make sense for men (Fair, 2018; McCloskey, Boonzaier, Steinbrenner, \& Hunter, 2016). We can see here that men with marginalised bodies argue, as do feminist scholars, that the job involves everyone-and not only those on the wrong end of power. Here, though, there is an inversion as Bongani's discussion is of women's power and women's role, instead of the usual discussions of male power.

\section{Concluding Notes and Take-Home Points}

We have seen in this chapter how the men who participated in our project really helped us understand some key issues about disability and masculinity. We heard about struggles with sex and sexuality and how these are dealt with both in intimate spaces, but also more broadly in terms of social roles. And we also saw how in being forced really to think about themselves and their masculinities, these men had interesting things to say about how to change the social and sexual order.

We would have liked to have talked more with these men, and to talk with a wider range of men, and especially with men who identified as LGBTIQA+. The small amount of information that we have is a limitation. But we have also seen that these small discussions can produce a richness of opinion and discussion, and we certainly have a lot to think about following this stage of our project. 


\section{REFERENCES}

Abbott, D., Carpenter, J., Gibson, B. E., Hastie, J., Jepson, M., \& Smith, B. (in press). Disabled men with muscular dystrophy negotiate gender. Disability \& Society.

Alldred, P., \& Fox, N. J. (2015). The sexuality-assemblages of young men: A new materialist analysis. Sexualities, 18(8), 905-920.

Anderson, E. (2005). Orthodox and inclusive masculinity: Competing masculinities among heterosexual men in a feminized terrain. Sociological Perspectives, $48(3), 337-355$.

Anderson, E. (2010a). In the game: Gay athletes and the cult of masculinity. New York, NY: Suny Press.

Anderson, E. (2010b). Inclusive masculinity: The changing nature of masculinities. London: Routledge.

Anderson, E., \& McCormack, M. (2018). Inclusive masculinity theory: Overview, reflection and refinement. Journal of Gender Studies, 27(5), $547-561$.

Anderson, E., \& McGuire, R. (2010). Inclusive masculinity theory and the gendered politics of men's rugby. Journal of Gender Studies, 19(3), 249-261.

Chadwick, S. B., \& van Anders, S. M. (2017). Do women's orgasms function as a masculinity achievement for men? The Journal of Sex Research, 54(9), 1141-1152.

Connell, R. W., \& Messerschmidt, J. W. (2005). Hegemonic masculinity: Rethinking the concept. Gender of Society, 19, 829-859.

Cornwall, A., \& Lindisfarne, N. (Eds.). (2016). Dislocating masculinity: Comparative ethnographies (2nd ed.). London: Taylor \& Francis.

De Boise, S. (2015). I'm not homophobic, "I've got gay friends": Evaluating the validity of inclusive masculinity. Men and Masculinities, 18(3), 318-339.

Fair, F. (2018). Subject/object/body: Recent perspectives on beauty and aesthetics in gender studies. WSQ: Women's Studies Quarterly, 46(1), 215220.

Garland-Thomson, R. (2009). Staring: How we look. Oxford: Oxford University Press.

Garland-Thomson, R. (Ed.). (1996). Freakery: Cultural spectacles of the extraordinary body. New York, NY: New York University Press.

Gough, B. (2018). Contemporary masculinities. London: Palgrave Pivot.

Held, V. (Ed.). (2018). Justice and care: Essential readings in feminist ethics. New York, NY: Routledge.

Kiguwa, P., \& Siswana, A. (2018). Layers of woundedness in Inxeba: Masculinities disrupted, denied and defamed. Image \& Text: A Journal for Design, 32(1), 1-13.

Kilvington, D., \& Price, J. (Eds.). (2017). Sport and discrimination. London: Taylor \& Francis. 
Kittay, E. F. (2013). Love's labor: Essays on women, equality and dependency. New York, NY: Routledge.

Kunzel, R. (2018). The rise of gay rights and the disavowal of disability in the United States. In M. Rembis, C. Kudlick, \& K. E. Nielsen (Eds.), The Oxford handbook of disability history (pp. 459-478). New York, NY: Oxford University Press.

Le Roux, R., Hendrik Niehaus, D. J., Koen, L., Seller, C., Lochner, C., \& Emsley, R. A. (2007). Initiation rites as a perceived stressor for IsiXhosa males with schizophrenia. Transcultural Psychiatry, 44(2), 292-299.

Liddiard, K. (2017). The intimate lives of disabled people. London: Routledge.

Liddiard, K., \& Slater, J. (2018). 'Like, pissing yourself is not a particularly attractive quality, let's be honest': Learning to contain through youth, adulthood, disability and sexuality. Sexualities, 21(3), 319-333.

Longmore, P. K. (2015). Telethons: Spectacle, disability, and the business of charity. New York, NY: Oxford University Press.

Magodyo, T., Andipatin, M., \& Jackson, K. (2017). The role of Xhosa traditional circumcision in constructing masculinity. South African Journal of Psychology, $47(3), 344-355$.

Magrath, R., \& Scoats, R. (2019). Young men's friendships: Inclusive masculinities in a post-university setting. Journal of Gender Studies, 28(1), 45-56.

Mandela, N. (1995). Long walk to freedom. New York, NY: Back Bay Books.

McCloskey, L. A., Boonzaier, F., Steinbrenner, S. Y., \& Hunter, T. (2016). Determinants of intimate partner violence in sub-Saharan Africa: A review of prevention and intervention programs. Partner Abuse, 7(3), 277-315.

McRuer, R. (2006). Crip theory: Cultural signs of queerness and disability. New York, NY: New York University Press.

McRuer, R. (2018). Crip times: Disability, globalization, and resistance. New York, NY: New York University Press.

Messerschmidt, J. W. (2019). The salience of "hegemonic masculinity". Men and Masculinities, 22(1), 85-91.

Mfecane, S. (2016). "Ndiyindoda" [I am a man]: Theorising Xhosa masculinity. Anthropology Southern Africa, 39(3), 204-214.

Mji, G., Schneider, M., Vergunst, R., \& Swartz, L. (2014). On the ethics of being photographed in research in rural South Africa: Views of people with disabilities. Disability and Society, 29, 714-723. Retrieved from http://dx. doi.org/10.1080/09687599.2013.844103.

O’Neill, R. (2015). Whither critical masculinity studies? Notes on inclusive masculinity theory, postfeminism, and sexual politics. Men and Masculinities, 18(1), 100-120.

Okeke-Ihejirika, P., Salami, B., \& Amodu, O. (in press). Exploring intimate partner violence from the perspective of African men: A meta-synthesis. Aggression and Violent Behavior. 
Porter, C. N., Douglas, N., \& Collumbien, M. (2017). 'Enhance her pleasure-and your grip strength': Men's Health magazine and pseudo-reciprocal pleasure. Culture, Health \& Sexuality, 19(7), 738-751.

Sandell, R., Dodd, J., \& Garland-Thomson, R. (Eds.). (2013). Re-presenting disability: Activism and agency in the museum. New York, NY: Routledge.

Scoats, R. (2017). Inclusive masculinity and Facebook photographs among early emerging adults at a British university. Journal of Adolescent Research, 32(3), 323-345.

Shahvaroughi Farahani, N., Sohrabi, F., Mazaherinejadfard, G., \& Hasan Larijani, M. (2018). Designing and testing a structural model of attachment styles and negative affects variables as predictors of young men's body dissatisfaction. International Journal of Behavioral Sciences, 12(1), 36-41.

Shakespeare, T. (1999). The sexual politics of disabled masculinity. Sexuality and Disability, 17(1), 53-64.

Shakespeare, T. (2000). Disabled sexuality: Toward rights and recognition. Sexuality and Disability, 18(3), 159-166.

Shakespeare, T. (2013). Disability rights and wrongs revisited. London: Routledge.

Shakespeare, T., \& Richardson, S. (2018). The sexual politics of disability, twenty years on. Scandinavian Journal of Disability Research, 20(1), 82-91.

Statistics South Africa (StatsSA). (2011). Gender statistics in South Africa, 2011. Retrieved from http://www.statssa.gov.za/publications/Report-03-1005/Report-03-10-052011.pdf.

Swartz, A., Colvin, C., \& Harrison, A. (2018a). The problem or the solution? Early fertility and parenthood in the transition to adulthood in Khayelitsha. South Africa. Reproductive Health Matters, 26(54), 145-154.

Swartz, L. (1986). Transcultural psychiatry in South Africa: Part I. Transcultural Psychiatric Research Review, 23(4), 273-303.

Swartz, L. (1987). Transcultural psychiatry in South Africa. Part II. Transcultural Psychiatric Research Review, 24(1), 5-30.

Swartz, L. (2018). Representing disability and development in the global south. Medical Humanities, 44(4), 281-284.

Swartz, L., Hunt, X., Watermeyer, B., Carew, M., Braathen, S. H., \& Rohleder, P. (2018b). Symbolic violence and the invisibility of disability. African Safety Promotion: A Journal of Injury and Violence Prevention, 16(2), 21-30.

Tronto, J. C. (1993). Moral boundaries: A political argument for an ethic of care. New York, NY: Psychology Press.

Williams, J. L. (2017). Media, performative identity, and the new American freak show. New York, NY: Palgrave Macmillan.

Yen, J., \& Wilbraham, L. (2003). Discourses of culture and illness in South African mental health care and indigenous healing, Part II: African Mentality. Transcultural Psychiatry, 40(4), 562-584. 
Open Access This chapter is licensed under the terms of the Creative Commons Attribution 4.0 International License (http://creativecommons.org/licenses/ by $/ 4.0 /$ ), which permits use, sharing, adaptation, distribution and reproduction in any medium or format, as long as you give appropriate credit to the original author(s) and the source, provide a link to the Creative Commons license and indicate if changes were made.

The images or other third party material in this chapter are included in the chapter's Creative Commons license, unless indicated otherwise in a credit line to the material. If material is not included in the chapter's Creative Commons license and your intended use is not permitted by statutory regulation or exceeds the permitted use, you will need to obtain permission directly from the copyright holder.

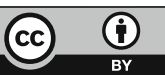

